\title{
Influence of aeration induced by piers on the starting position of the flow aeration and extreme pressures in stepped spillways
}

\section{Influência da aeração induzida por pilares na posição de aeração do escoamento e nas pressões extremas em vertedouros em degraus}

Priscila dos Santos Priebe ${ }^{1}$ (D), Rute Ferla ${ }^{1}$ (D), Carolina Kuhn Novakoski ${ }^{1}$ (D), Aline Saupe Abreu ${ }^{1}$ (D), Eder Daniel Teixeira ${ }^{1}$ (D), Mauricio Dai Prá $^{1}$ (D) \& Marcelo Giulian Marques $^{1}$ (D)

${ }^{1}$ Instituto de Pesquisas Hidráulicas, Universidade Federal do Rio Grande do Sul, Porto Alegre, RS, Brasil

E-mails: priscilaspriebe@gmail.com (PSP), ruteferla@hotmail.com (RF), carolkn04@gmail.com (CKN), alsaupe@gmail.com (ASA), eder.teixeira@ufrgs.br (EDT),mauricio.daipra@ufrgs.br (MDP),mmarques@iph.ufrgs.br (MGM)

\begin{abstract}
The operation of stepped spillways is limited by a range of discharges due to the risk of occurrence of the cavitation phenomenon and erosion on its steps. Since there is a demand for spillways with the possibility of overflow of greater discharges, the designs seek to increase the air concentration of the flow, which can occur through the installation of piers in the spillway in order to protect the structure from the above mentioned damage. The aim of this work is to analyze flow characteristics and extreme minimum and maximum pressures with non-exceedance probability of $0.1 \%$ and $99.9 \%$ acting next to the step edges of the spillway with aeration induced by piers through an experimental analysis in a physical model. Based on the results obtained, flow behavior was defined and equations for predicting the extreme pressures that occur along the stepped spillway with aeration induced by piers were proposed.
\end{abstract}

Keywords: Pre-aeration; Aerators; Physical model; Aerated flow.

\section{RESUMO}

Vertedouros em degraus têm sua operação limitada a faixas de vazões devido ao risco de ocorrência do fenômeno de cavitação e erosão em seus degraus. Como há demanda por vertedouros com possibilidade de extravasamento de maiores vazões, procura-se aumentar a concentração de ar do escoamento, que pode ocorrer através da instalação de pilares no vertedouro, para assim proteger a estrutura contra os referidos danos. O objetivo deste trabalho é avaliar as características do escoamento e as pressões extremas mínimas e máximas com probabilidade de $0,1 \%$ e $99,9 \%$ de não-excedência, atuantes nas quinas dos degraus do vertedouro com aeração induzida por pilares, através da análise experimental em um modelo físico. Baseado nos resultados obtidos foi definido o comportamento do escoamento e foram propostas equações de previsão das pressões extremas que ocorrem ao longo do vertedouro em degraus com aeração induzida por pilares.

Palavras-chave: Pré-aeração; Aeradores; Modelo físico; Escoamento aerado. 
Influence of aeration induced by piers on the starting position of the flow aeration and extreme pressures in stepped spillways

\section{INTRODUCTION}

Stepped spillways are characterized by the significant energy dissipation that occurs during the passage of the flow through the chute due to the macroroughness imposed by the steps. In addition, air entrainment in the flow over these structures is anticipated, compared to the flow of smooth chute spillways, which increases the flow length with a biphasic characteristic, reducing the risk of damage by cavitation.

The structure is more susceptible to risks of damage caused by cavitation, especially at the step edges, in the non-aerated zone upstream from the inception point of natural aeration. As the unit discharge increases, the inception point of natural aeration moves downstream, exposing a larger region of the structure to such risks.

Several studies on stepped spillways were developed to understand the flow behavior and hydrodynamic efforts that occur along the stepped chute, such as the studies published by Povh et al. (2004), Sánchez-Juny et al. (2007, 2008), Arantes et al. (2009), Takahashi \& Ohtsu (2012), Conterato et al. (2015), Estrella et al. (2015), Xu et al. (2015), Dai Prá et al. (2016), Zhang \& Chanson (2016, 2017, 2018), Osmar et al. (2018) and Nóbrega et al. (2020). Based on the knowledge of hydrodynamic pressures on the steps, studies found the implementation of stepped spillways to be limited to a range of discharges due to the risk of cavitation damage.

Novakoski et al. (2018) found that the range of maximum specific discharge in which cavitation inception occurs lies between 11 and $17 \mathrm{~m}^{2} / \mathrm{s}$. Amador et al. (2009) indicated a maximum specific discharge of approximately $15 \mathrm{~m}^{2} / \mathrm{s}$, in order to avoid cavitation occurrence. In the study of Gomes (2006), the critical unit discharges that would lead to the occurrence of cavitation are on the order of 11.3 to $15.6 \mathrm{~m}^{2} / \mathrm{s}$. According to Matos et al. (2000), the phenomenon of cavitation will begin when the unit discharge lies between 20 and $30 \mathrm{~m}^{2} / \mathrm{s}$, a limit higher than the limit presented by other authors. Frizell et al. (2013, 2015) conducted experiments in a non-aerated closed conduit able to induce the cavitation phenomenon, which simulates the situation observed on stepped spillways. The authors indicated a cavitation number between $0.60-0.65$ for chutes with a slope of $68.2^{\circ}$ and between $0.30-0.40$ for slope of $21.8^{\circ}$.

Taking into consideration the demand for higher flows and the advantages associated with stepped spillways, it is important to predict methods to prevent cavitation damage in these structures. Peterka (1953) suggested that the presence of small quantities of air in the flow, about $7 \%$ of the ratio between the air and water volumes, can reduce, or even eliminate erosion damage caused by cavitation. That occurs due to the air water mixture compressibility, which alleviates the impact of vapour bubbles implosion. One way is to increase the air concentration in the flow upstream from the inception point of natural aeration, which can be achieved through induced aeration.

Studies on stepped spillways with induced aeration, i.e. with the introduction of air into the flow through aerator devices (deflectors, piers, among others), were developed aiming at increasing the operational range of specific flow that can be discharged into the stepped spillways without damaging the hydraulic structures. The use of piers in stepped spillways was investigated in the studies of Si-ying et al. (2012), Calitz (2015), Koen (2017) and Koen et al. (2019) through physical models with different pier geometries. These studies show that the piers form lateral and inferior cavities in the flow, allowing the air to be incorporated into the flow, thus anticipating the start of aeration.

To date, studies have been carried out on stepped spillways with aeration induced by piers, however there are still knowledge gaps, especially regarding the evaluation of pressures exerted by the flow on the steps. Thus, the aim of the present work is, through the flow behavior submitted to varied discharges, to evaluate the flow characteristics and minimum and maximum extreme pressures with a non-exceedance probability of $0.1 \%$ and $99.9 \%$ acting next to the step edges of a spillway with aeration induced by piers. This research also aims to determine dimensionless parameters, which allows the prediction of extreme pressures and flow characteristics position.

\section{MATERIALS AND METHODS}

The experimental study was developed in a physical model of a stepped spillway installed at the Laboratório de Hidráulica Experimental of Furnas Centrais Elétricas with a geometric scale ratio of 1:10 for the transposition of its values. The model, built in concrete, has a Creager-type ogee, is $1.15 \mathrm{~m}$ wide, a stepped chute with a slope of $1 \mathrm{~V}: 0,75 \mathrm{H}\left(53.13^{\circ}\right)$, and steps that are $0.09 \mathrm{~m}$ high.

Piers were installed on the sides of the spillway, from the beginning of the ogee until the first step (Figure 1). The piers are $0.075 \mathrm{~m}$ wide, and the upstream extremity has a circular geometry with a radius of $0.075 \mathrm{~m}$. This allows the width between two consecutive piers of the model to be representative of the width commonly used in a prototype.

The flow depths on the first step $\left(h_{0}\right)$ were measured using a common point gauge installed in the central axis of the channel perpendicular to stepped chute pseudo-bottom.

The characteristic behaviors of the flow along the stepped chute, related to the flow aeration, were visually identified through flow observation during the testing procedure and analysis of the videos recorded. The characteristic flow positions recorded were (Figure 2): (1) position where the beginning of air bubbles occurs in the inferior layer of the flow and (2) position where the boundary layer reaches the flow free surface.

The dynamic pressures acting on the steps were measured with pressure transducers connected to the chute through by hoses $0.20 \mathrm{~m}$ long and with a diameter of $0.017 \mathrm{~m}$, according to the recommendation of Lopardo (1996) and Trierweiler Neto (2006). The pressure taps were located in the central line of the model chute, next to the step edges (Figure 1) of the horizontal faces of steps number $2,4,5,8,9,11,12,15$ and 16 and of the vertical faces of steps number 2, 3, 5, 7, 8, 11, 12, 14 and 15. ZURICH pressure transducers, model PSI.420 and accuracy of $0.1 \%$ full scale were utilized, operating in the following range according to the pressure taps position: -1 to $2 \mathrm{mH}_{2} \mathrm{O}$ for the horizontal faces of steps 2, 4 and 5 and all the vertical faces of the steps and -1 to $3 \mathrm{mH}_{2} \mathrm{O}$ for the horizontal faces of steps $8,9,11,12$, 15 and 16. The tests were conducted with a frequency of $100 \mathrm{~Hz}$ for 10 minutes, simultaneously for all tapping points considered.

Tests were carried out on the stepped spillway model considering induced and natural aeration (in this case, without any aerator device), in order to compare the behavior of both configurations. Table 1 shows the total and unit discharges tested on 

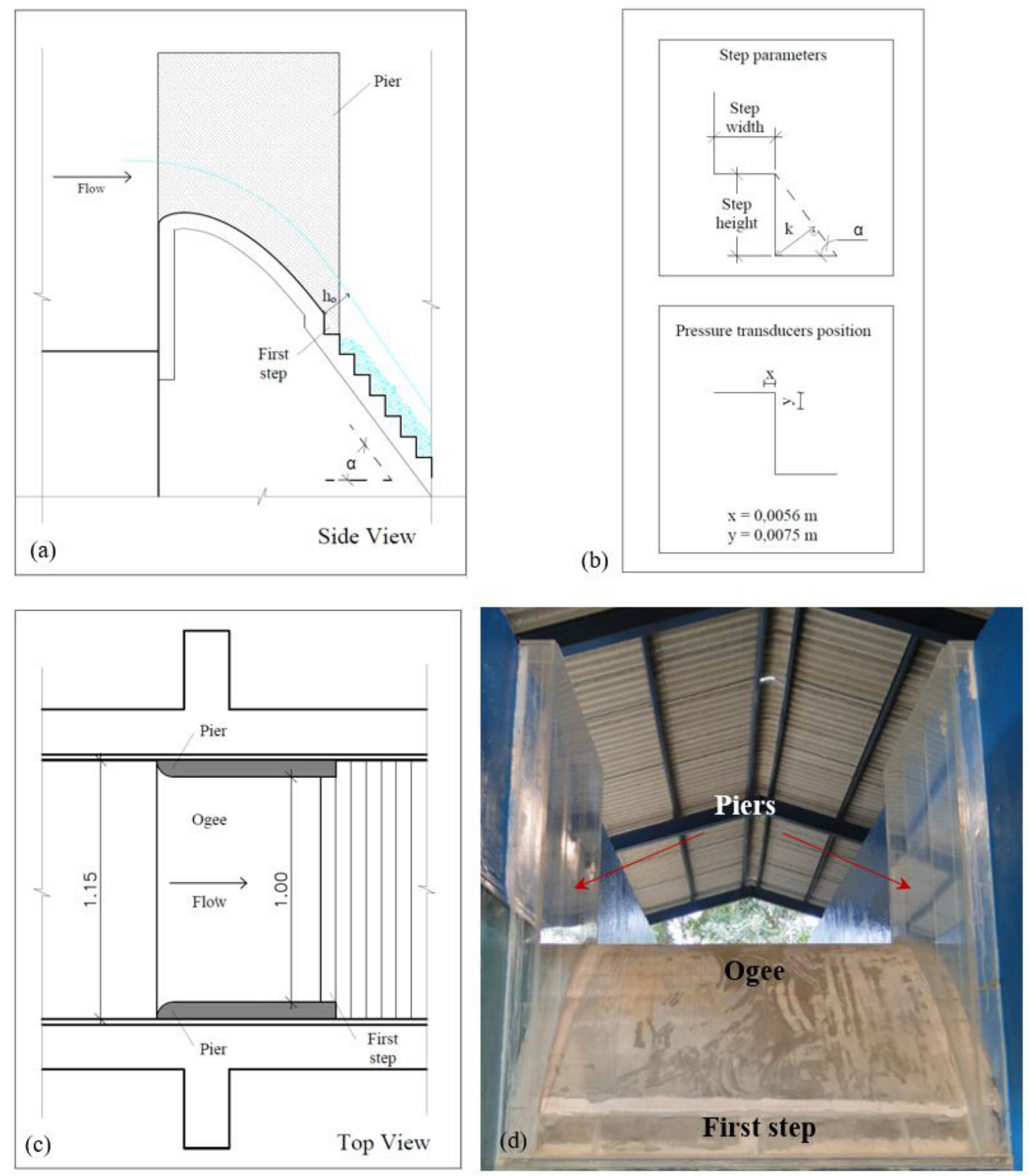

Figure 1. Schematic representation of the physical model, where (a) side view; (b) step parameters and position of pressure transducers; (c) top view; and (d) frontal view.

Table 1. Total and unit discharges on the model and prototype and roughness Froude number.

\begin{tabular}{cccc}
\hline $\begin{array}{c}\text { Q model } \\
(\mathbf{1} / \mathbf{s})\end{array}$ & $\begin{array}{c}\text { q model } \\
\left(\mathbf{m}^{2} / \mathbf{s}\right)\end{array}$ & $\begin{array}{c}\text { q prototype } \\
\left(\mathbf{m}^{2} / \mathbf{s}\right)\end{array}$ & $\mathbf{F}^{*}$ \\
\hline 115 & 0.100 & 3.2 & 2.85 \\
144 & 0.125 & 3.9 & 3.56 \\
173 & 0.150 & 4.8 & 4.27 \\
230 & 0.200 & 6.3 & 5.69 \\
316 & 0.275 & 8.7 & 7.82 \\
380 & 0.330 & 10.5 & 9.38 \\
\hline
\end{tabular}

the model, the unit discharge on the prototype and the roughness Froude number $\left(\mathrm{F}^{*}\right)$, which is represented by Equation 1.

$$
F^{*}=\frac{q}{\sqrt{g \operatorname{sen} \alpha k^{3}}}
$$

where $\mathrm{q}$ is the unit discharge $\left[\mathrm{m}^{2} / \mathrm{s}\right], \mathrm{g}$ is the gravitational acceleration $\left[\mathrm{m} / \mathrm{s}^{2}\right], \alpha$ is the chute angle with the horizontal $\left[^{\circ}\right], \mathrm{k}$ is the step roughness [m], as shown in Figure 1.

The characteristic positions of the flow with induced aeration, as well as the lowest minimum pressure with a non- 
exceedance probability of $0.1 \%$ and the highest maximum pressure with a non-exceedance probability of $99.9 \%$ were analyzed in dimensional and also dimensionless form.

\section{RESULTS AND DISCUSSION}

\section{Behavior of the flow with aeration induced by piers}

The visual analyses of the flow on the stepped spillway with aeration induced by piers show two characteristic regions: the region where the lower flow aeration occurs and the region of the superficial flow aeration, as shown in Figure 3.

The flow regions are represented based on the characteristic positions (Figure 3a), which were measured longitudinally from the spillway crest. For the induced aeration, these positions are called starting position of the lower flow aeration $\left(\mathrm{PLA}_{\mathrm{p}}\right)$ and starting position of the superficial flow aeration $\left(\mathrm{PSA}_{\mathrm{p}}\right)$.

Region of lower aeration: it occurs in the lower part of the flow, does not reach the whole water depth and evolves due to the narrowing of the chute caused by the presence of the piers (Figure $3 \mathrm{~b}$ and $3 \mathrm{c}$ ). The air is incorporated in the lower air

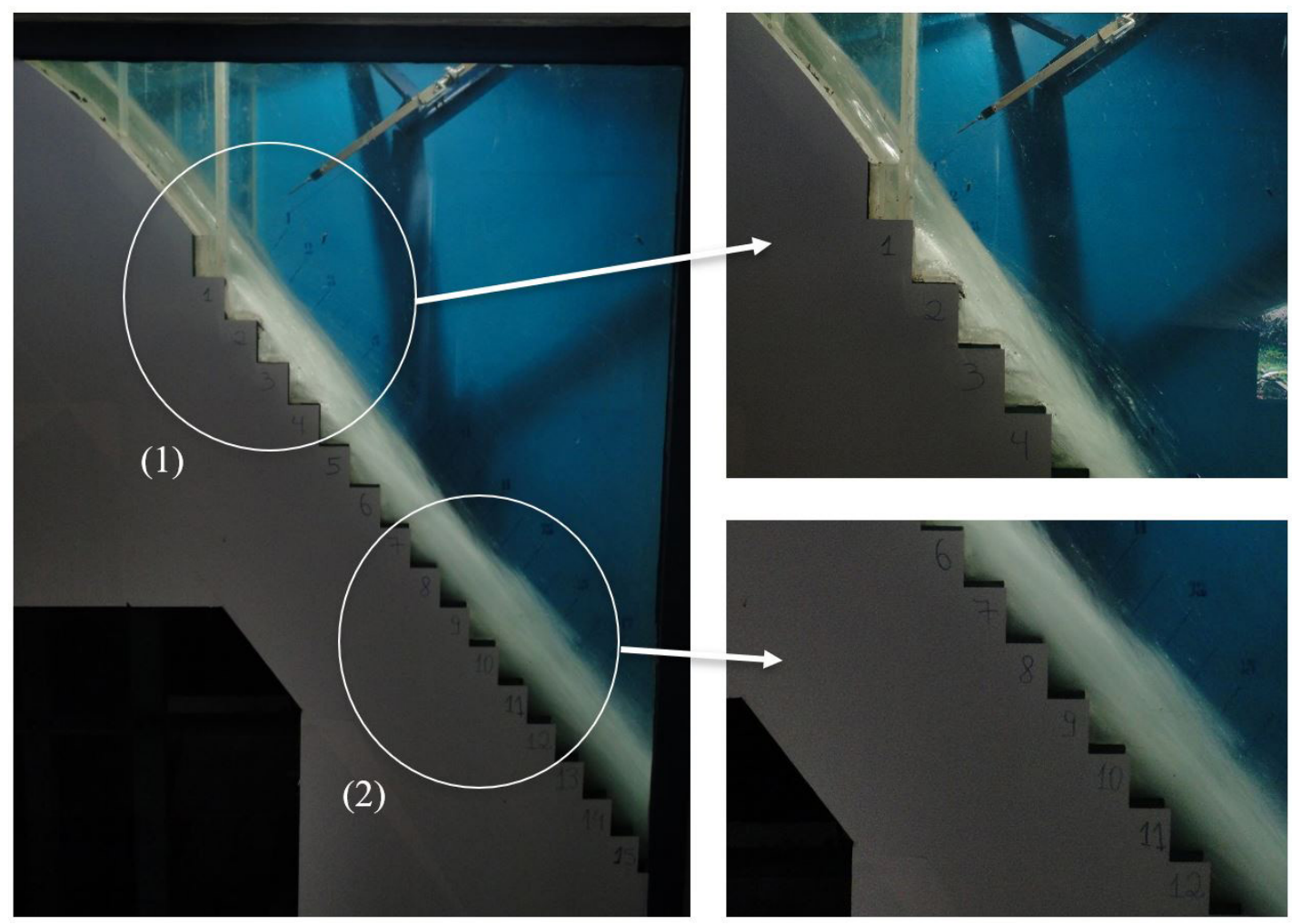

Figure 2. Characteristic positions of flow with aeration induced by piers for a unit discharge of $0.200 \mathrm{~m}^{2} / \mathrm{s}$.
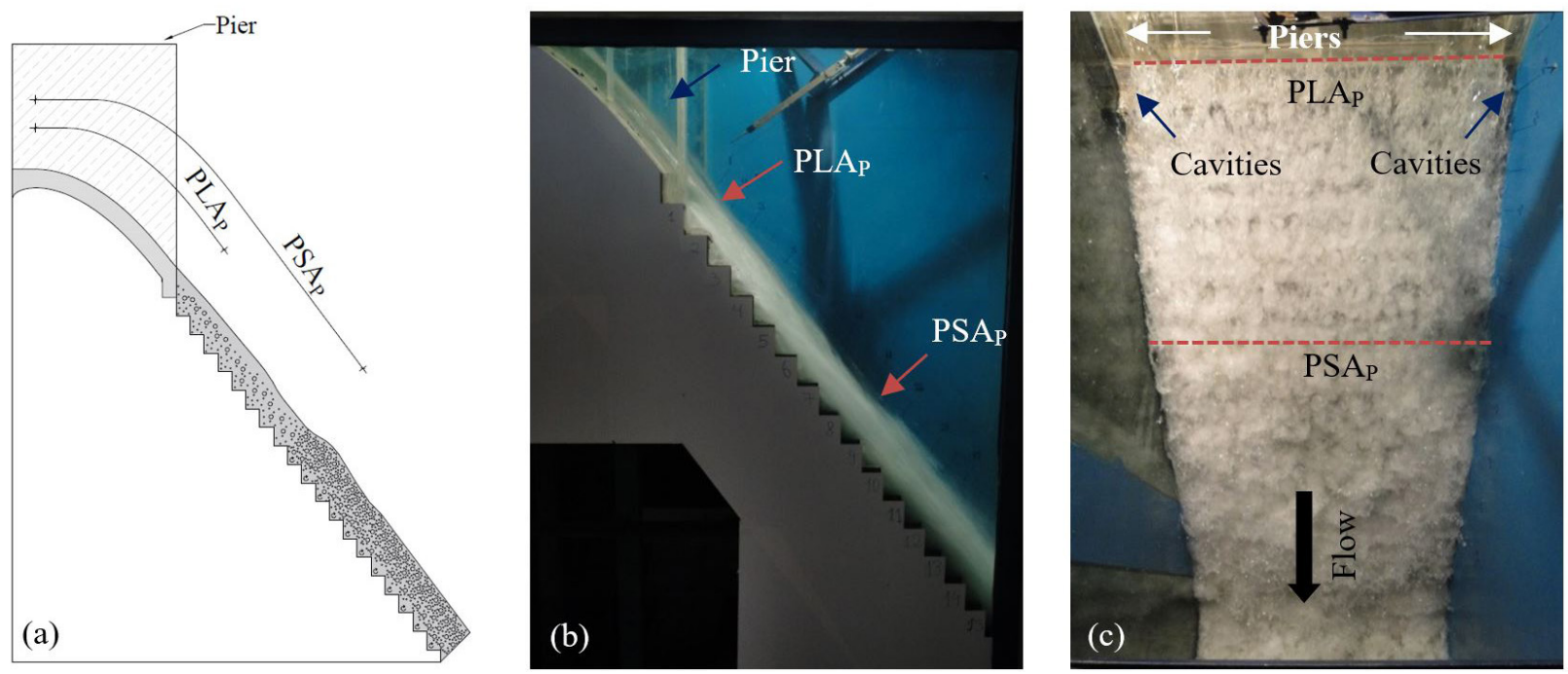

Figure 3. Behavior of the flow with induced aeration for the unit discharge of $0.200 \mathrm{~m}^{2} / \mathrm{s}$, where (a) schematic drawing; (b) side view; and (c) top view. 
water interface through the cavities formed just downstream of the piers as also determined by Si-ying et al. (2012) and Calitz (2015). The PLA $A_{p}$ begins from the second step of the spillway for all unit discharges tested.

Region of superficial flow aeration: it occurs downstream from the lower aeration when the boundary layer reaches the free surface of the flow (Figure $3 \mathrm{~b}$ and $3 \mathrm{c}$ ).

The PSA obtained are shown in Figure $4 \mathrm{a}$ and compared to the starting positions of superficial flow aeration for natural aeration $\left(\mathrm{PSA}_{\mathrm{N}}\right)$. Figure $4 \mathrm{~b}$ shows the $\mathrm{PSA}_{\mathrm{p}}$ made dimensionless by the flow depth on the first step $\left(h_{0}\right)$, as shown in Figure 1a, on the ordinate axis and the roughness Froude number of the step $\left(\mathrm{F}^{*}\right)$ on the abscissa axis.

The PSA $A_{\mathrm{N}}$ grows almost linearly with the increase of the unit discharge. On the other hand, for the induced aeration, the specific flow exerts less influence on the PSA $A_{p}$, i.e. the PSA remains practically constant with the increase of the specific flow, oscillating between the longitudinal positions 1.80 and $1.90 \mathrm{~m}$.

These results indicate that the lower air incorporation affected the behavior of the superficial aeration, since the PSA has occurred on the second step from the deflector, regardless of the unit discharge tested, which makes PSA $A_{\mathrm{p}}$ occur in a practically constant longitudinal position. That does not happen with natural aeration, in which PSA ${ }_{\mathrm{N}}$ is influenced by the unit discharge increase. For lower discharges, up to the unit discharges of $0.200 \mathrm{~m}^{2} / \mathrm{s}$, $\mathrm{PSA}_{\mathrm{p}}$ has occurred downstream in relation to $\mathrm{PSA}_{\mathrm{N}}$, as shown in Figure $4 \mathrm{a}$. For higher unit discharges, the $\mathrm{PSA}_{\mathrm{p}}$ occurred in upstream longitudinal positions in comparison to $\mathrm{PSA}_{\mathrm{N}}$.

Based on the behavior of the dimensionless number of the $\mathrm{PSA}_{\mathrm{p}}$ and $\mathrm{PSA}_{\mathrm{N}}$, it is observed that, as the $\mathrm{F}^{*}$ increases, the dimensionless numbers decrease, due to the increase of the flow depth on the first step $\left(h_{0}\right)$. Equation 2 and Equation 3 were adjusted to represent these behaviors, respectively.

$$
\begin{aligned}
& \frac{P S A_{P}}{h_{0}}=133.36 F^{*-0.969} \\
& \frac{P S A_{N}}{h_{0}}=52.78 F^{*-0.302}
\end{aligned}
$$

The power law equations (Equation 2 and Equation 3) showed a determination coefficient of 0.99 and 0.94 , respectively, indicating that the equations allow for an approximate prediction of where the superficial aeration of the flow will begin for a stepped spillway with induced aeration (Equation 2) and natural aeration (Equation 3) and with $\mathrm{F}^{*}$ between 2.5 and 10.0.

The main uncertainties associated with Equation 2 and Equation 3 are related to PSA and $\mathrm{h}$ measures, due to the flow dynamics. The PSA was determined by the same observer considering the same criteria. It was observed that a variation of 1 or 2 steps may occur. However, the $h_{o}$ parameter is not significantly influenced by the free surface instability due to the presence of tranquilizers which guarantee homogeneous flow distribution. In addition, at this location, flow is monophasic, which reduces flow instability, thus the observed mean variation is around $1 \mathrm{~mm}$.

\section{Extreme minimum and maximum pressures}

Knowledge regarding the pressures acting on a stepped spillway structure is important for its correct dimensioning. Lopardo (1996) recommends the use of minimum extreme pressures with a non-exceedance probability of $0.1 \%$ to identify the cavitation inception processes. The extreme pressures associated with the non-exceedance probabilities of $0.1 \%$ (representing the minimum pressures) and $99.9 \%$ (representing the maximum pressures) allow an estimation of the minimum and maximum values that the pressure can reach along the stepped spillway.

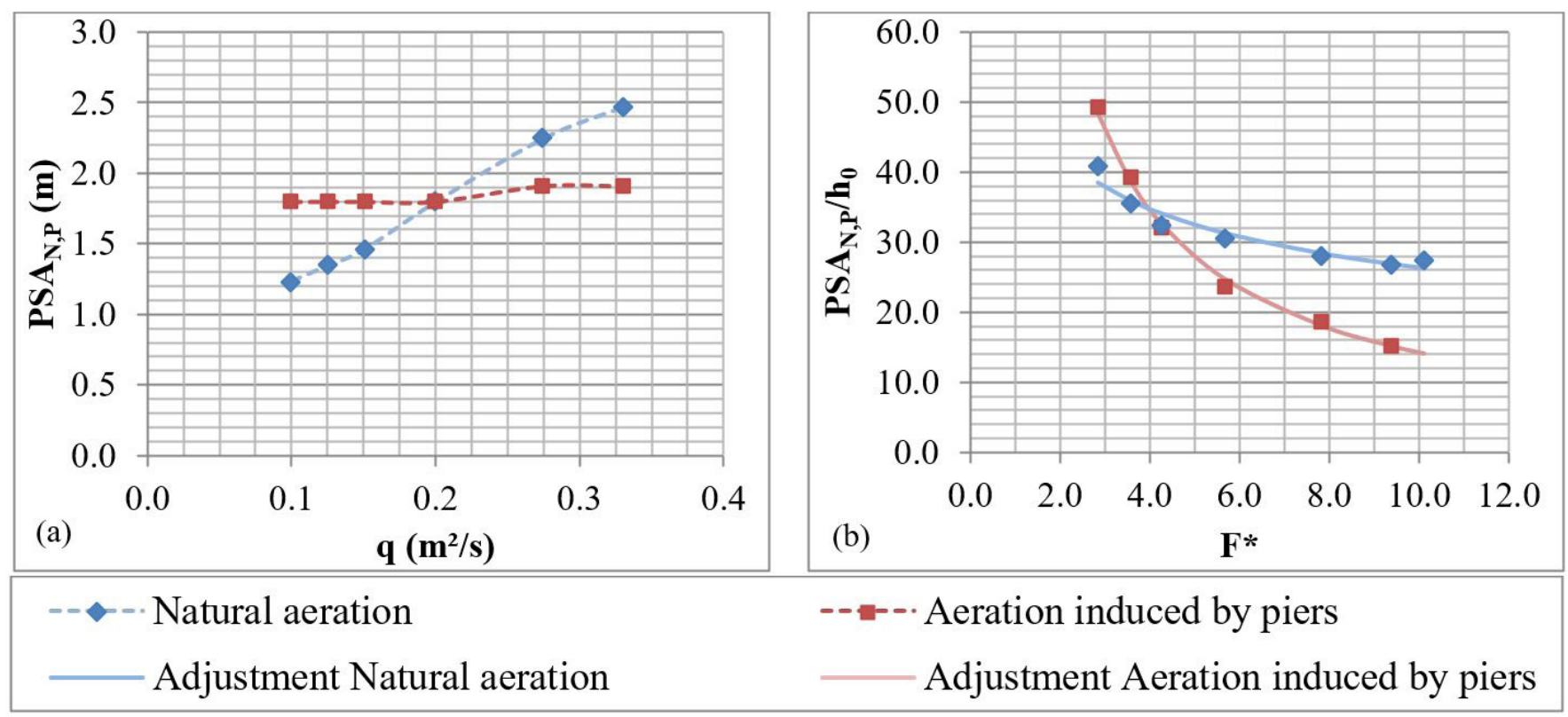

Figure 4. (a) Starting position of superficial induced aeration and natural aeration; (b) dimensionless number of the starting position of superficial induced aeration and natural aeration. 
Figure $5 \mathrm{a}$ and $5 \mathrm{~b}$ shows the behavior of the lowest values of minimum extreme pressures with a non-exceedance probability of $0.1 \%\left(\mathrm{P}_{0.1 \%}\right)$ of the induced aeration in comparison to the natural aeration, for the horizontal and vertical faces. Figure $5 \mathrm{c}$ and (d) shows, respectively, the behavior of the highest values of maximum extreme pressures with non-exceedance probability of $99.9 \%\left(\mathrm{P}_{99.9 \%}\right)$ of induced aeration in comparison to the natural aeration, for the horizontal and vertical faces.

The lowest values of $\mathrm{P}_{0.1 \%}$ and the highest values of $\mathrm{P}_{99.9 \%}$ for natural and induced aeration presented similar behaviors. In general, as the unit discharge increases, the lowest values of $\mathrm{P}_{01 \%}$ decrease and the highest values of $\mathrm{P}_{99.9 \%}$ increase, both for the horizontal and the vertical faces. The vertical faces presented the highest extreme pressure with a non-exceedance probability $0.1 \%$, and the horizontal faces presented the highest extreme pressure with a non-exceedance probability of $99.9 \%$.

The pressure loads for the horizontal faces of induced aeration were more extreme for all unit discharges tested. In other words, for the lowest values of $\mathrm{P}_{0.1 \%}$, the induced aeration presented pressure loads an average of $0.10 \mathrm{mH}_{2} \mathrm{O}$ lower than the natural aeration. For the highest values of $\mathrm{P}_{99.9 \%}$, the induced aeration presented pressure loads an average of $0.30 \mathrm{mH}_{2} \mathrm{O}$ higher than the natural aeration.

For the vertical faces, the induced aeration presented the lowest values of $\mathrm{P}_{0.1 \%}$ higher than the natural aeration and the highest values of $\mathrm{P}_{99.9 \%}$ lower than the natural aeration, for unit discharges between 0.100 and $0.150 \mathrm{~m}^{2} / \mathrm{s}$. However, for the highest unit discharges tested, the pressure loads of induced aeration were more extreme for both non-exceedance probabilities.

Therefore, the minimum and maximum extreme pressures of the vertical faces for the induced aeration were attenuated for unit discharges lower than $0.200 \mathrm{~m}^{2} / \mathrm{s}$, indicating the influence of the lower air incorporated to the flow through the piers, even though the superficial aeration of the flow had not been anticipated for these unit discharges.
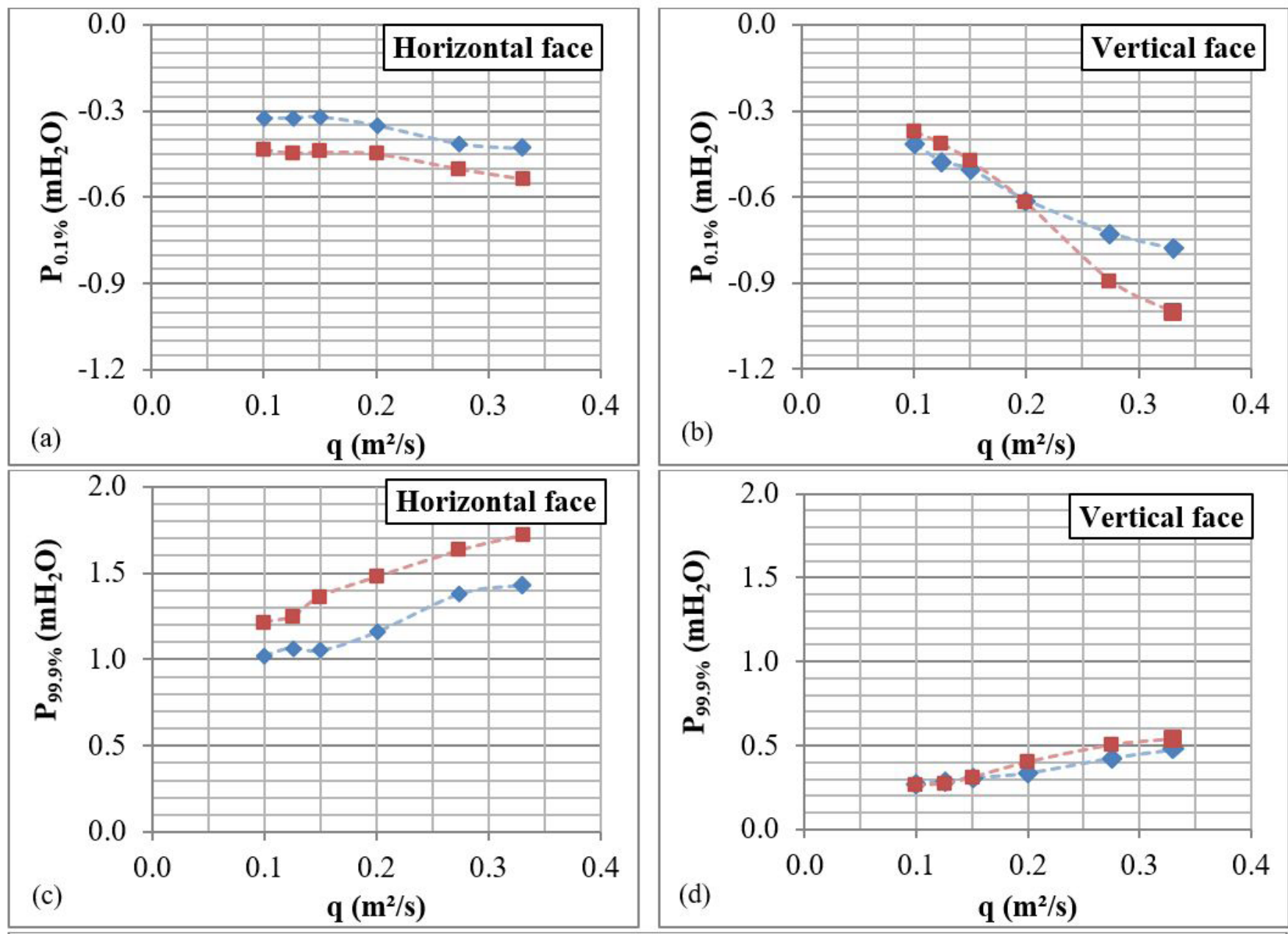

$---\cdot$ Natural aeration

----Aeration induced by piers

Figure 5. Extreme pressures (a) $\mathrm{P}_{0.1 \%}$ for the horizontal faces, (b) $\mathrm{P}_{0.1 \%}$ for the vertical faces, (c) $\mathrm{P}_{99.9 \%}$ for the horizontal faces e (d) $\mathrm{P}_{99.9 \%}$ for the vertical faces, in function of the unit discharge, considering both situations of induced and natural aeration. 
Figure 6 shows the behavior of the lowest minimum pressures with a non-exceedance probability of $0.1 \%$ and the highest maximum pressures with a non-exceedance probability of $99.9 \%$ for the horizontal and vertical faces, made dimensionless by the flow depth on the first step $\left(h_{0}\right)$.

The dimensionless numbers that represent the lowest minimum pressures with non-exceedance probability of $0.1 \%$ increase as the $\mathrm{F}^{*}$ increases. However, this does not mean that the $\mathrm{P}_{0.1 \%}$ values increase with the increase of the $\mathrm{F}^{*}$. In fact, the flow depth on the first step $\left(h_{0}\right)$ increases as the $F^{*}$ increases.

The same occurs for dimensionless numbers that represent the highest values of maximum pressure with a non-exceedance probability of $99.9 \%$, which decrease with the increase of the $\mathrm{F}^{*}$, due to the increase of flow depth on the first step $\left(\mathrm{h}_{0}\right)$.

Equation 4 allows the evaluation of the value of the dimensionless relation $\left(\frac{P_{0}}{h_{0}}\right)$ to estimate the magnitude of the minimum pressures with a non-exceedance probability of $0.1 \%$ and the maximum pressures with a non-exceedance probability of
$99.9 \%$ on the horizontal and vertical faces, depending on the $\mathrm{F}^{*}$. Table 2 shows the ( $\mathrm{a}, \mathrm{b}$ and $\mathrm{c}$ ) coefficients and the determination coefficient between the adjusted curve and the experimental data made dimensionless.

$$
\frac{P_{\%}}{h_{0}}=\frac{F^{*}}{\left(a+b F^{*}+c F^{* 2}\right)}
$$

The reciprocal quadratic equations for the horizontal and vertical faces present a determination coefficient between 0.86 and 0.99 , indicating that the dimensionless numbers allow an approximate prediction of the lowest minimum pressures with a non-exceedance probability of $0.1 \%$ and of the highest maximum pressures with a non-exceedance probability of $99.9 \%$ for the horizontal and vertical faces of the induced aeration, for $\mathrm{F}^{*}$ between 2.5 and 10.0 .

The longitudinal position where the lowest and highest extreme pressures occur is close to the starting position of the superficial aeration. Thus Equation 2 allows an approximate
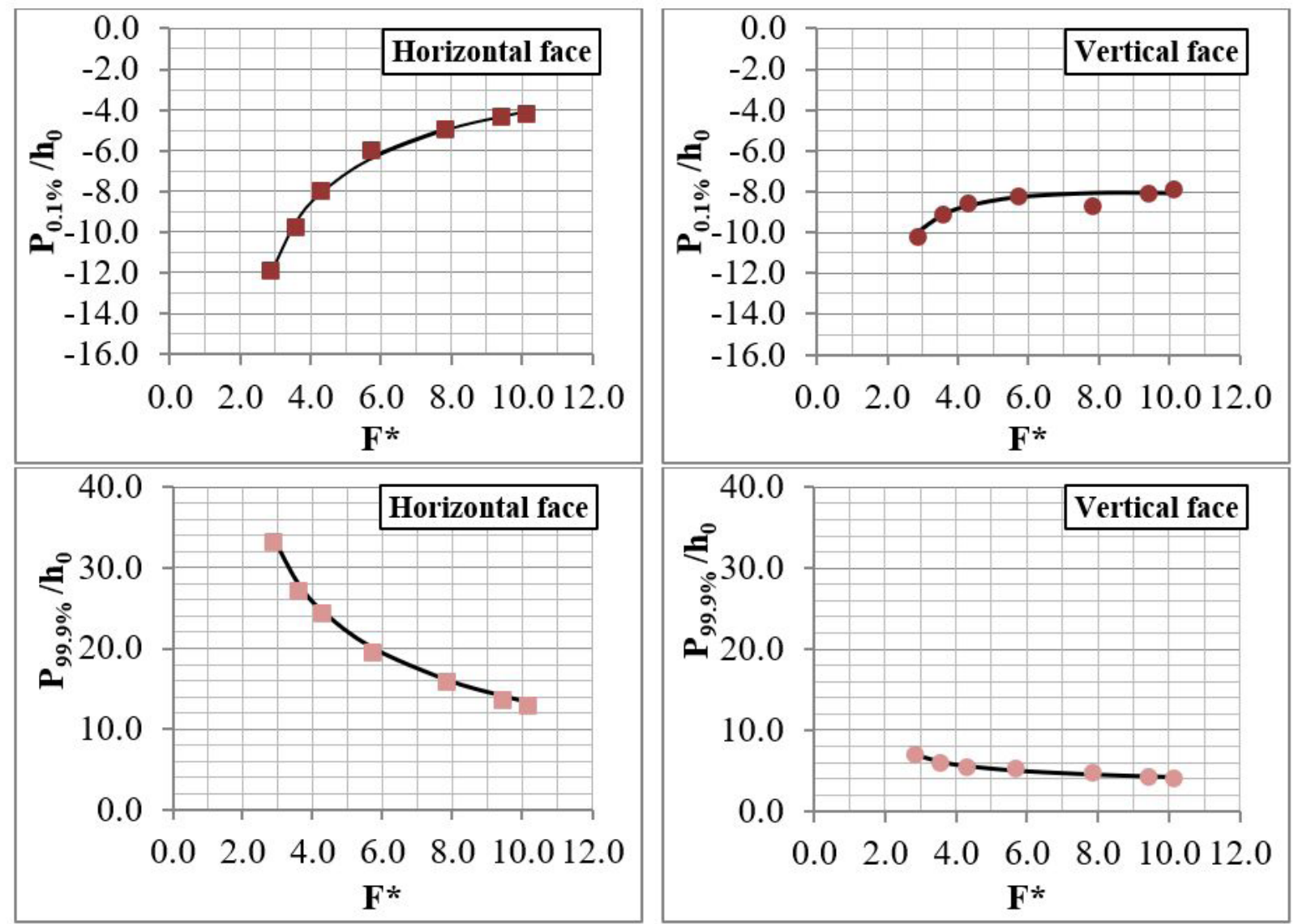

Aeration induced by piers - non-exceedance probability of $0.1 \%$ - Horizontal faces

Aeration induced by piers - non-exceedance probability of $0.1 \%$ - Vertical faces

- Aeration induced by piers - non-exceedance probability of $99.9 \%$ - Horizontal faces

- Aeration induced by piers - non-exceedance probability of $99.9 \%$ - Vertical faces

Adjustment

Figure 6. Extreme dimensionless pressures next to the step edges, in function of the roughness Froude number of induced aeration. 
Influence of aeration induced by piers on the starting position of the flow aeration and extreme pressures in stepped spillways

Table 2. a, b and c coefficients obtained for Equation 3 and the determination coefficient $\left(\mathrm{R}^{2}\right)$ for the prediction of the lowest minimum pressures with a non-exceedance probability of $0.1 \%\left(\mathrm{P}_{0.1 \%}\right)$ and of the highest maximum pressures with a non-exceedance probability of $99.9 \%\left(\mathrm{P}_{99.9 \%}\right)$ on the horizontal and vertical faces.

\begin{tabular}{clcccc}
\hline & & $\mathbf{a}$ & $\mathbf{b}$ & $\mathbf{c}$ & $\mathbf{R}^{2}$ \\
\hline \multirow{2}{*}{$\mathrm{P}_{0.1 \%}$} & Horizontal face of the step & 0.130 & -0.077 & -0.018 & 0.99 \\
\multirow{2}{*}{$\mathrm{P}_{99.9 \%}$} & Vertical face of the step & 0.153 & -0.159 & 0.002 & 0.86 \\
& Horizontal face of the step & -0.034 & 0.027 & 0.005 & 0.99 \\
& Vertical face of the step & -0.250 & 0.219 & 0.004 & 0.97 \\
\hline
\end{tabular}

prediction of the region in which these values will occur for a certain prototype of stepped spillways with induced aeration and the indicated $\mathrm{F}^{*}$.

\section{CONCLUSIONS}

Based on the evaluation of the flow behavior characteristics of the physical model of a stepped spillway, it has been found that flow with induced aeration differs from the behavior of the natural aeration. This occurs due to the installation of piers, which provokes a discontinuity of the flow that favors the incorporation of air into the lower part of the flow before the starting position of superficial aeration.

The increase of the unit discharge has an insignificant effect on the superficial aeration, because the longitudinal position in which it occurs is practically stable, whereby for the unit discharges of the model that are higher than $0.200 \mathrm{~m}^{2} / \mathrm{s}$, the longitudinal position of the superficial aeration start was anticipated in relation to the natural aeration.

The lowest values of minimum extreme pressure load and the highest values of maximum extreme pressure load for the horizontal and vertical faces occurred for the configurations of induced aeration. In general, the maximum pressure loads were not attenuated with the implementation of air incorporation devices into the flow and were more extreme than the natural aeration of the flow. These conclusions were not observed for the lowest unit discharges tested in the model (between 0.100 and $0.150 \mathrm{~m}^{2} / \mathrm{s}$ ), because in these situations of induced aeration the lower air incorporated into the flow through the piers was sufficient to attenuate the minimum and maximum extreme pressure loads.

However, based on the visual analysis, for all conditions tested the air was introduced into the lower part of the flow, which is in contact with the structure right at the beginning of the stepped chute, thus showing the possibility of protecting the concrete structure from possible damage caused by the cavitation phenomenon. This hypothesis should be extended by carrying out analyses of the air concentration in the flow with induced aeration.

Besides, it was possible to make an approximate prediction of the minimum and maximum extreme pressures, as well as of the starting position of the superficial aeration, which is close to the region where the lowest and highest extreme pressures occur for a certain prototype of stepped spillway with induced aeration and $\mathrm{F}^{*}$ between 2.5 and 10.0 .

\section{NOTATION}

The following symbols are used in this paper: $\mathrm{a}, \mathrm{b}, \mathrm{c}=$ regression coefficients;

$\mathrm{F}^{*}=$ roughness Froude number;

$\mathrm{g}=$ gravitational acceleration $\left[\mathrm{m} / \mathrm{s}^{2}\right]$;

$\mathrm{h}_{0}=$ flow depth on the first step $[\mathrm{m}]$;

$\mathrm{K}=$ step roughness $[\mathrm{m}]$;

$\mathrm{PLA}_{\mathrm{p}}=$ starting position of the lower flow aeration for induced aeration $[\mathrm{m}]$;

PSA $_{\mathrm{N}}=$ starting position of superficial flow aeration for natural aeration $[\mathrm{m}]$;

$\mathrm{PSA}_{\mathrm{p}}=$ starting position of the superficial flow aeration for induced aeration $[\mathrm{m}]$;

$\mathrm{P}_{0.1 \%}=$ minimum extreme pressures with non-exceedance probability of $0.1 \%\left[\mathrm{mH}_{2} \mathrm{O}\right]$;

$\mathrm{P}_{99.9 \%}=$ maximum extreme pressures with non-exceedance probability of $99.9 \%\left[\mathrm{mH}_{2} \mathrm{O}\right]$;

$\mathrm{q}=$ unit discharge $\left[\mathrm{m}^{2} / \mathrm{s}\right]$;

$\mathrm{Q}=\operatorname{discharge}\left[\mathrm{m}^{3} / \mathrm{s}\right]$;

$\mathrm{R}^{2}=$ determination coefficient;

$\alpha=$ chute angle with the horizontal $\left[{ }^{\circ}\right]$.

\section{ACKNOWLEDGEMENTS}

To Furnas Centrais Elétricas for financing the research project "Analysis of macroturbulence in stepped spillways with forced aeration (pre-aeration)", as well as to the Coordenação de Aperfeiçoamento de Pessoal de Nível Superior (CAPES) and the Conselho Nacional de Desenvolvimento Científico e Tecnológico (CNPQ) for granting research scholarships. The authors also thank the scholarship holders of the Laboratório de Obras Hidráulicas at the Instituto de Pesquisas Hidráulicas (IPH-UFRGS) for their support in the testing and data analysis process.

\section{REFERENCES}

Amador, A., Sánchez-Juny, M., \& Dolz, J. (2009). Developing flow region and pressure fluctuations on steeply sloping stepped spillways. Journal of Hydraulic Engineering, 135(12), 1092-1100. http:/ / dx.doi.org/10.1061/(ASCE)HY.1943-7900.0000118.

Arantes, E. J., Porto, R. M., Passig, F. H., \& Carvalho, K. Q. (2009). Uso de ferramenta de fluidodinâmica computacional no estudo da aeração ao longo de vertedouros em degraus. In Anais do XVIII Simpósio Brasileiro de Recursos Hídricos. Campo Grande: ABRH. Retrieved in 2020, June 10, from https://www.abrhidro.org.br/ SGCv3/publicacao.php?PUB $=3 \& I D=110 \& S U M A R I O=2020$

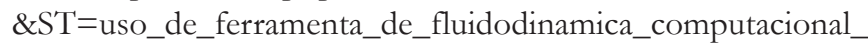
no_estudo_da_aeracao_ao_longo_de_vertedouros_em_degraus 
Calitz, J. A. (2015). Investigation of air concentration and pressures of a stepped spillway equipped with a crest pier (Masters dissertation). Stellenbosch University, Stellenbosch. Retrieved in 2020, May 28, from https://scholar.sun.ac.za/handle/10019.1/97775

Conterato, E., Marques, M. G., \& Alves, A. A. M. (2015). Proposta de uniformização das equações de previsão das características do escoamento sobre a calha de um vertedouro em degraus. Revista Brasileira de Recursos Hídricos, 20(1), 131-137. http:/ /dx.doi. org/10.21168/rbrh.v20n1.p131-137.

Dai Prá, M., Priebe, P. S., Sanagiotto, D. G., \& Marques, M. G. (2016). Dissipação de energia do escoamento deslizante sobre turbilhões em vertedouros em degraus de declividade $1 \mathrm{~V}: 1 \mathrm{H}$. Ingeniería del Agua, 20(1), 1-12. http://dx.doi.org/10.4995/ia.2016.3714.

Estrella, S., Sánchez-Juny, M., Bladé, E., \& Dolz, J. (2015). Physical modeling of a stepped spillway without sidewalls. Canadian Journal of Civil Engineering, 42(5), 311-318. http://dx.doi.org/10.1139/ cjce-2014-0427.

Frizell, K. W., Renna, F. M., \& Matos, J. (2013). Cavitation potential of flow on stepped spillways. Journal of Hydraulic Engineering, 139(6), 630-636. http://dx.doi.org/10.1061/(ASCE)HY.1943-7900.0000715.

Frizell, K. W., Renna, F. M., \& Matos, J. (2015). Closure to "Cavitation Potential of Flow on Stepped Spillways". Journal of Hydraulic Engineering, 141(8), 07015009. http://dx.doi.org/10.1061/ (ASCE)HY.1943-7900.0001009.

Gomes, J. F. (2006). Campo de pressões: condições de incipiência à cavitação em vertedouros em degraus com declividade 1V:0,75H (Doctoral thesis). Instituto de Pesquisas Hidráulicas, Universidade Federal do Rio Grande do Sul, Porto Alegre. Retrieved in 2020, June 10, from https://www.lume.ufrgs.br/handle/10183/11336

Koen, J. (2017). Artificial aeration on stepped spillways with piers and flares to mitigate cavitation damage (Masters dissertation). Stellenbosch University, Stellenbosch. Retrieved in 2020, May 28, from https:/ / scholar.sun.ac.za/handle/10019.1/102964

Koen, J., Bosman, D. E., \& Basson, G. R. (2019). Artificial aeration of stepped spillways by crest piers and flares for the mitigation of cavitation damage. Journal of the South African Institution of Civil Engineering, 61(2), 28-38. http://dx.doi.org/10.17159/2309$8775 / 2019 / v 61$ n2a3.

Lopardo, R. A. (1996). Modelacion fisica de flujo macroturbulento en estructuras hidraulicas. Apuntes de Ingeniería, 19(2), 5-20.

Matos, J., Quintela, A. C., \& Ramos, C. M. (2000). Sobre a protecção contra a erosão de cavitação em descarregadores de cheias em degraus. Recursos Hídricos, 21(3), 91-96.

Nóbrega, J. D., Matos, J., Schulz, H. E., \& Canelas, R. B. (2020). Smooth and stepped spillway modeling using the SPH method. Journal of Hydraulic Engineering, 146(8), 186-199. http://dx.doi. org/10.1061/(ASCE)HY.1943-7900.0001776.
Novakoski, C. K., Priebe, P. S., Canellas, A. V. B., Saraiva, L. S., Dai Prá, M., Sanagiotto, D. G., Osmar, F. M., Pinto, C. P. S., Marques, M. G., \& Matos, J. (2018). Extreme negative pressures and cavitation tendency on steeply sloping stepped spillways. In Proceedings for the 3rd International Dam World Conference. Foz do Iguaçu: IBRACON. Retrieved in 2020, June 19, from https:// lume.ufrgs.br/bitstream/handle/10183/187234/001082448. pdf? sequence $=1$ \&is Allowed $=\mathrm{y}$

Osmar, F. M., Canellas, A. V. B., Priebe, P. S., Saraiva, L. S., Teixeira, E. D., \& Marques, M. G. (2018). Analysis of the longitudinal distribution of pressures near the ends of the vertical and horizontal faces in stepped spillway of slope 1V: 0.75H. Revista Brasileira de Recursos Hídricos, 23(4), e4. http://dx.doi.org/10.1590/23180331.0318170057.

Peterka, A. J. (1953, August-September). The effect of entrained air on cavitation pitting. Paper presented at the International Association for Hydraulic Research and Hydraulics Division of the American Society of Civil Engineers, Minneapolis.

Povh, P. H., Taniguchi, E. R., \& Ota, J. J. (2004). Início da aeração e pressões ao longo de vertedouros em degraus. Revista Brasileira de Recursos Hidricos, 9(1), 97-111. http://dx.doi.org/10.21168/ rbrh.v9n1.p97-111.

Sánchez-Juny, M., Bladé, E., \& Dolz, J. (2007). Pressures on a stepped spillway. Journal of Hydraulic Research, 45(4), 505-511. http://dx.doi.org/10.1080/00221686.2007.9521785.

Sánchez-Juny, M., Bladé, E., \& Dolz, J. (2008). Analysis of pressures on a stepped spillway. Journal of Hydraulic Research, 46(3), 410-414. http://dx.doi.org/10.3826/jhr.2008.3152.

Si-ying, W., Dong-mei, H., \& Cai-huan, W. (2012). Aerator of stepped chute in Murum Hydropower Station. Procedia Engineering, 28, 803-807. http://dx.doi.org/10.1016/j.proeng.2012.01.813.

Takahashi, M., \& Ohtsu, I. (2012). Aerated flow characteristics of skimming flow over stepped chutes. Journal of Hydraulic Research, 50(4), 427-434. http://dx.doi.org/10.1080/00221686.2012.702859.

Trierweiler Neto, E. F. (2006). Avaliação do campo de pressões em ressalto bidráulico formado a jusante de uma comporta com diferentes graus de submergência (Masters dissertation). Instituto de Pesquisas Hidráulicas, Universidade Federal do Rio Grande do Sul, Porto Alegre. Retrieved in 2020, June 10, from https://lume.ufrgs.br/ handle/10183/8132.

Xu, W., Luo, S., Zheng, Q., \& Luo, J. (2015). Experimental study on pressure and aeration characteristics in stepped chute flows. Science China. Technological Sciences, 58(4), 720-726. http://dx.doi. org/10.1007/s11431-015-5783-6.

Zhang, G., \& Chanson, H. (2016). Hydraulics of the developing flow region of stepped spillways. I: physical Modeling and boundary layer development. Journal of Hydraulic Engineering, 142(7), 04016015. http:/ /dx.doi.org/10.1061/(ASCE)HY.1943-7900.0001138. 
Zhang, G., \& Chanson, H. (2017). Self-aeration in the rapidlyand gradually-varying flow regions of steep smooth and stepped spillways. Environmental Fluid Mechanics, 17(1), 27-46. http://dx.doi. org/10.1007/s10652-015-9442-z.

Zhang, G., \& Chanson, H. (2018). Application of local optical flow methods to high-velocity free-surface flows: validation and application to stepped chutes. Experimental Thermal and Fluid Science, 90, 186-199. http://dx.doi.org/10.1016/j.expthermflusci.2017.09.010.

\section{Authors contributions}

Priscila dos Santos Priebe: Model conception, methodology elaboration, data analysis, graphics elaborations, bibliographic review, text elaboration.

Rute Ferla: Methodology elaboration, data analysis, text review.
Carolina Kuhn Novakoski: Methodology elaboration, data analysis, text review.

Aline Saupe Abreu: Data analysis, text review.

Eder Daniel Teixeira: Model conception, methodology elaboration, text review.

Mauricio Dai Prá: Model conception, methodology elaboration, data analysis, text review.

Marcelo Giulian Marques: Model conception, methodology elaboration, data analysis, text review.

Editor-in-Chief: Adilson Pinheiro

Associated Editor: Edson Cezar Wendland 